\title{
Prader-Willi syndrome after age 15 years
}

\author{
BERNARD M LAURANCE, A BRITO, AND J WILKINSON \\ Queen Elizabeth Hospital for Children, London
}

SUMmary Twenty-four patients, all of them over 15 years, with the Prader-Willi syndrome are described. Obesity, often extreme, associated with an insatiable appetite, was their principal handicap and this was made worse by educational subnormality and hypogonadism. Three of them developed diabetes. Each attended a special school or an adult training centre. Although most of them were of short stature and had scoliosis, 2 were tall but they were even more severely mentally retarded than is usually the case. Nine other patients died aged between 3 and 23 years. The most common cause of death was cor pulmonale.

Features of eponymous syndromes are difficult to remember, but there is no obvious alternative name for the well-defined clinical features which characterise the Prader-Willi (PW) syndrome. The syndrome was described in Switzerland about 25 years ago ${ }^{1-2}$ and in England 6 years later. ${ }^{3}$ At least 170 patients have been reported with the syndrome but only about 20 of them have been adults. ${ }^{4-6}$ Twenty-four patients over age 15 years are described here.

\section{Patients}

This paper describes the clinical features in 24 patients who are still alive and aged over 15 years; 13 of them are male (age range 15-41 years) and 11 are female (age range 15-29 years). Reference is also made to 9 others who died aged between 3 and 23 years. All were born to non-consanguineous white parents, from widely-ranging social classes, and had no known similarly affected siblings.

Appetite. Seventeen of the 24 patients had insatiable appetites so that frequently food had to be locked away. One stole food from a hospital dustbin and another from the dog's bowl. Of 9 patients considered by their parents not to eat excessively, 8 accepted some food restriction.

Facies. Although coarser, all had facies characteristic of infancy and childhood-close-set, almond-shaped eyes, prominent nasal bridge, and open mouth-and these persisted into adult life.

Weight and height. All were excessively fat and some were so gross (Fig. 1) that they could only be weighed on commercial scales. Twenty-two patients were very short-more than 2 standard deviations below correct height for weight (Fig. 2). However two young men (aged 15 and 26) were tall, and they may represent a variant of the PW syndrome. Each had all the usual features but, in both, obesity had started at about 1 year instead of between 2 and 4 years of age, and mental retardation was more severe (IQ <50); their facies, although similar to those

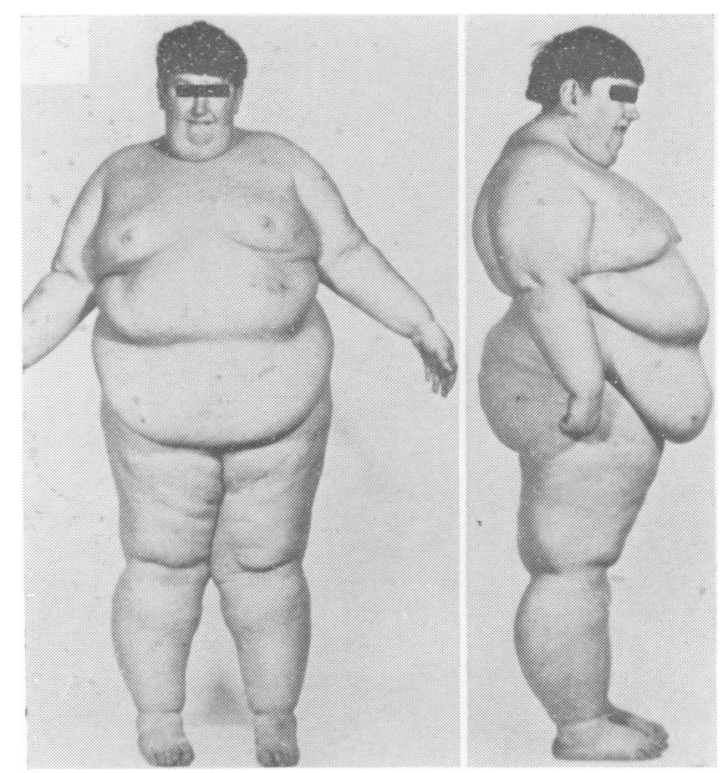

Fig. 1 Obesity, characteristic in adults with the Prader-Willi syndrome (age 25). (Same patient as in Fig. 5). 
182 Laurance, Brito, and Wilkinson

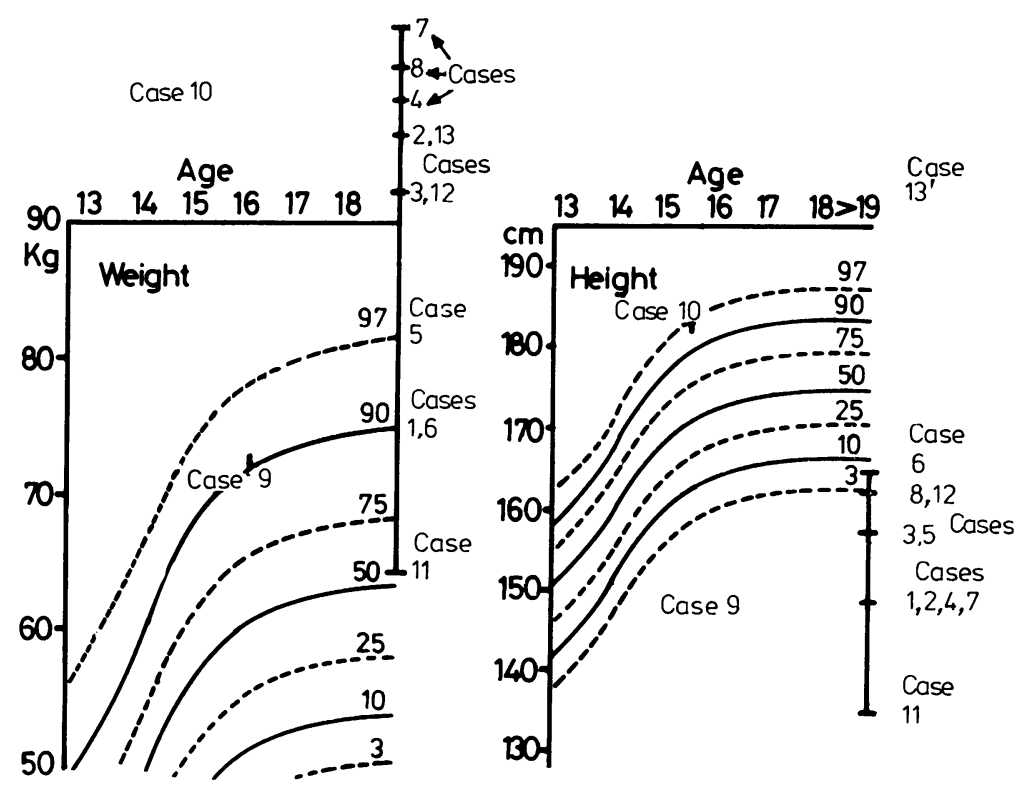

Fig. 2 Heights and weights of the males. (Females are similar).
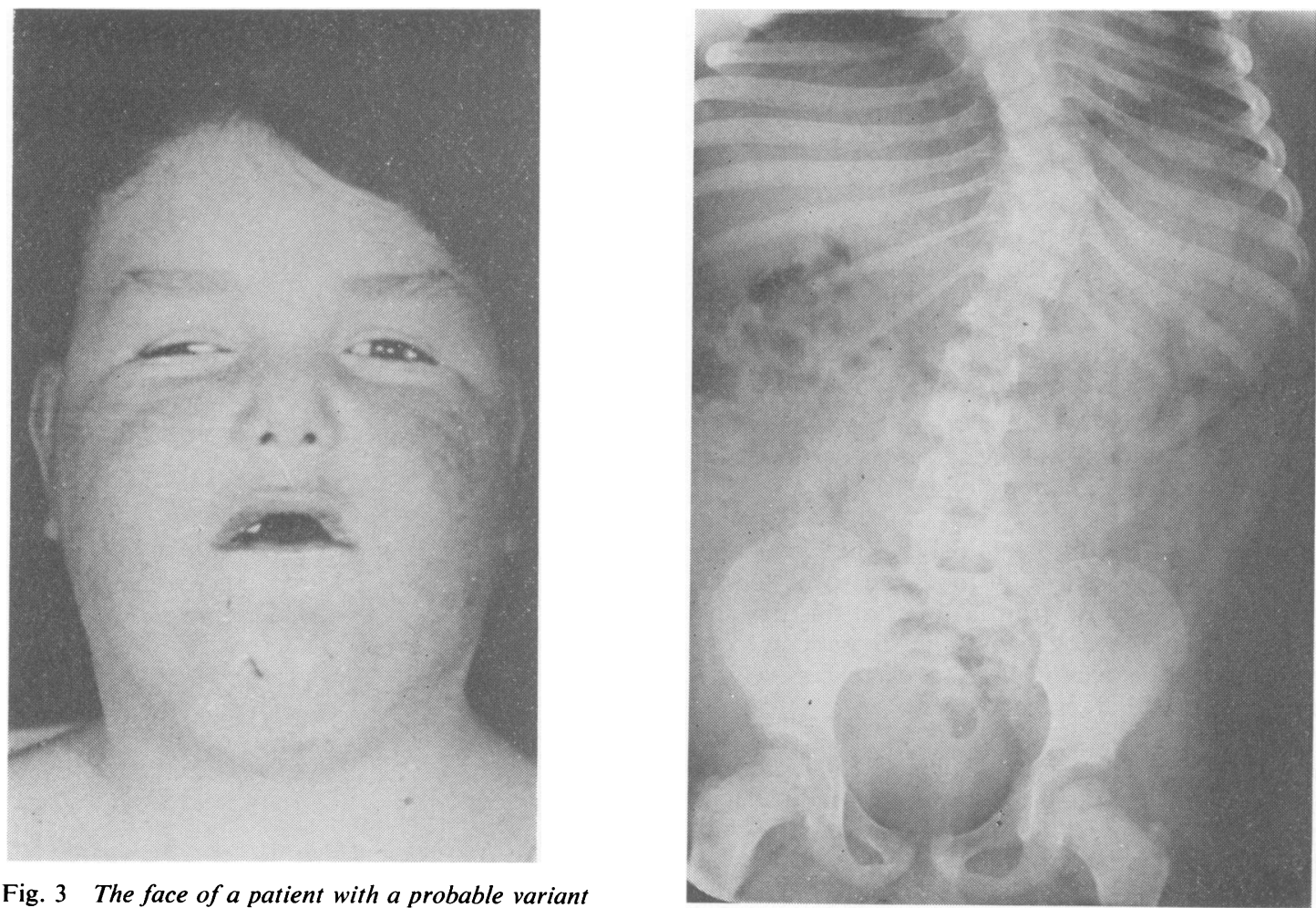

Fig. 3 The face of a patient with a probable variant of the Prader-Willi syndrome. Compare it with the typical facies (see Fig 1).

Fig. 4 Typical scoliosis. 


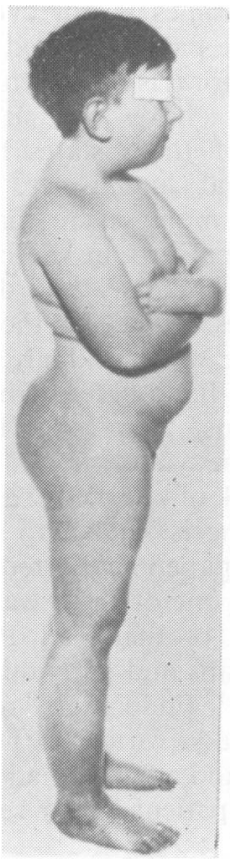

Fig. 5 Stance suggesting scoliosis at age 7 years. (Reproduced by courtesy of the editor of Clinical Endocrinology)

characteristic of the PW syndrome, were flatter and the jaw more square (Fig. 3).

Scoliosis. Scoliosis was present clinically in $15(62 \%)$ of the 24 patients and was present radiologically in 14 of the same 15 who had $x$-ray films taken (Fig. 4). In some it was recognisable in early childhood by the characteristic stance (Fig. 5) which became more obvious later. Two patients required operative correction (one of whom died postoperatively).

Hands, legs, and feet. All had small hands with a straight ulnar border compared with the normal slight curve (Fig. 6), whereas only one parent had a similar straight ulnar border. One sister, also mentally retarded but not with the PW syndrome, had bilateral straight ulnar borders. All patients had large thighs with lower legs tapering to very small feet. Three boys wore adult shoe sizes 6-8; the remainder wore sizes smaller than 5 . All the women wore size 3 or smaller. Pin-prick sensitivity was diminished in arms and legs which presumably accounted for sores in these areas, often secondarily infected from scratching. Despite this, the silky texture of their skin was characteristic even at age 40 years.

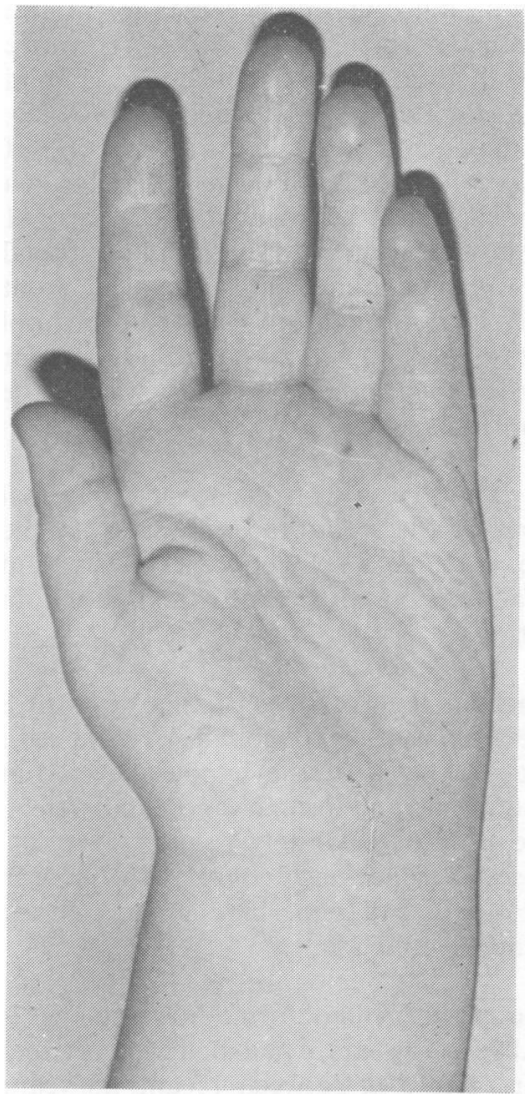

Fig. 6 Straight ulnar border characteristic of the Prader-Willi syndrome.

Secondary sex characteristics. One man shaved infrequently and the others did not shave at all. All had unbroken voices. Both axillary and pubic hair were sparse in both sexes. One or both testes were impalpable in 9 men and in the remaining 4 the testicular volume was $<8 \mathrm{ml} .{ }^{7}$ 'Pseudobreasts' due to excess fat were common in both sexes and it was impossible to tell whether glandular tissue was present in the women. Menses were absent in 9 of the 11 women. One had menstruated regularly each month (menarche aged $11 \frac{1}{2}$ years) while one other had had her first 'period' at 17 years, two between 18 and 27 years, and thereafter she had menstruated about every 6 weeks.

Intellect. The naive friendliness characteristic in childhood continued into adult life although some patients became stubborn and liable to sudden, short-lived bursts of temper, described by several 
parents as 'rages', but only one became violent and smashed objects. None seemed able to move quickly enough to attack other people. One man had strangled pets as a child but was no longer aggressive. Intelligence testing placed some in the lower range of normal in early childhood but by age 7 years only a few still attended a normal school and by age 11 years all were at educationally subnormal or special schools. All lived at home and attended adult training centres except for one at a boarding school for the educationally subnormal, one in a hostel for mentally retarded men, and 2 in a hospital for the mentally subnormal.

Somnolence. This was an almost universal accompaniment of the syndrome, especially in the grossly obese patients who slept excessively and often would fall asleep and become cyanosed within minutes of sitting.

Endocrine function. Results of endocrine tests in 8 patients suggested that the hypogonadism was due to malfunction at the level of the hypothalamus but there was additional and primary gonadal defect. These data are reported separately. ${ }^{8}$

Oral glucose tolerance tests were performed in 23 patients. Four had diabetic blood sugar curves, and 3 were clinically diabetic.

Deaths and necropsy findings. In addition to the 24 patients still alive at 15 years, 4 had died aged between 3 and 14 years, and 5 at between 17 and 23 years. Only 2 died in hospital and 4 had examinations at necropsy including the 14-year-old boy who died after an operation for scoliosis. The deaths were the result of cardiorespiratory failure and this was also certified to be the cause for death in the patients in whom no necropsy was done. Obesity complicated by scoliosis was considered to be contributory. One 17-year-old youth had a 'gastric exclusion' for his extreme obesity after which suturing of his rectus abdominis muscle proved very difficult. He died postoperatively and permission for necropsy was refused (H H Nixon, 1979, personal communication). In only one of the 4 necropsies was the brain studied histologically and it was normal.

\section{Discussion}

Despite our lack of knowledge about the aetiology, the features of the PW syndrome constitute a recognisable clinical pattern. The straight ulnar border of the hand (Fig. 6) is particularly characteristic but the cause is not known. A decline in growth has been reported ${ }^{9-10}$ which we believe is often the result of scoliosis. Scoliosis is very common although it sometimes is not evident, even radiologically, until the patient is aged between 5 and 10 years; the reason for it is unknown.

Some patients have normal stature or are tall; and both of these states have been associated with normal intelligence, and with mental retardation even more severe than is usual in the syndrome. Two patients in the current series were tall and severely mentally retarded, but otherwise they had features typical of the syndrome. Their facial appearances were strikingly similar to Hall and Smith's patient. ${ }^{9}$ It does seem that there are some clinical variations from the features generally associated with the syndrome.

Despite the lack of knowledge about the aetiology, the PW syndrome is known to be rarely familial. There are only 4 patients reported who had similarly affected siblings; one of the 4 was a twin, and both he and another brother had PW syndrome.11-12 Affected 1st cousins and parental consanguinity are both reported. ${ }^{4912}$ Endo et al. ${ }^{13}$ reported a family in which one male had a variant of the Lawrence-MoonBiedl syndrome and a female had the PW syndrome. One 30-year-old patient in our series has a Mongol sister.

Chromosomes are generally normal, although Dunn et al. ${ }^{14}$ reported a patient with an extra small chromosome resembling 21-22, and one patient with a long Y6. After a patient with a 15/15 translocation was reported, ${ }^{15}$ nine other abnormalities, mainly affecting the D group, were described. More recently Fraccaro et al. ${ }^{16}$ reported a $15 / 15$ centric fusion in 3 cases. This abnormality was also found in a normal woman whose chromosomes were examined because of habitual abortion, ${ }^{17}$ but Polani considers that an abnormality of chromosome 15 may be shown eventually in the PW syndrome (P E Polani, 1979, personal communication).

Few other investigations have been abnormal. Bone age was at least 2 years retarded after the age of about 5 years in 30 to $50 \%$ of patients s $^{5-618}$ and characteristic cranio-facial abnormalities were reported in skull $x$-ray films. ${ }^{40}$ Muscle enzyme studies, electromyographs, and muscle biopsies have all been normal ${ }^{6}{ }^{18-19}$ but further studies are needed.

Diabetes was less common in this syndrome than had originally been thought. Of the patients tested in this series, $4(20 \%)$ had diabetic blood sugar curves $13 \%$ of whom required insulin; Illig et al. ${ }^{20}$ reported that $10(83 \%)$ of 12 patients aged 15 years had diabetic blood sugar curves including $2(20 \%)$ who had diabetes. They found the incidence of abnormal glucose tolerance was increased after 15 years.

All patients were hypogonadal although some female patients menstruated occasionally or even regularly. ${ }^{512}$ Premature adrenarche ${ }^{51221}$ and sexual 
precocity ${ }^{22}$ are also recorded and we have seen the former in a 10-year-old girl. Pubic hair is invariably scanty. Hypergonadotrophic hypogonadism is also reported. ${ }^{23}$ We know of no fertility that has occurred. Normal testicular biopsies were reported earlier ${ }^{18}$ but more recently abnormalities of testicular morphology have been described - such as interstitial cell defects, tubular atrophy, hyalinisation, absence of the germinal cell layer, and lack of spermatogenesis. ${ }^{50-21}{ }^{24-26}$ It appears that testicular dysplasia is one of the reasons for the hypogonadism. That there is both a hypothalamic and a gonadal disorder is mentioned earlier.

Regrettably there are few reports on brain histology, particularly of the hypothalamus, and more studies are needed. In one necropsy, John Emery found a pituitary stalk that was perhaps thinner than normal, and an abnormal pattern of chromophobes which had karyohectic-type nuclei and an increased amount of cytoplasm (J L Emery, 1978, personal communication). There were also small collections of periodic acid-Schiff-positive colloid lying between cells and apparently outside blood vessels. It will not be known whether this fact is significant until there are reports on further necropsy findings.

Medical care. The prognosis for life of these patients appeared to depend on the degree of obesity; dietary management was the most difficult problem. Their naive charm and apparent lack of appetite control, coupled with moderate mental retardation, persuaded all but their closest relatives to succumb to their plea for food. A few learned to avoid excessive eating. The majority caused havoc in their homes not only because food stores had to be locked but also because their parents and siblings could not eat at the same table without having their plates raided. Appetite suppressants were universally useless. A strict diet ( 300 calories a day) was rarely accepted by the over 15 -year olds but, in the few cases where it was, the patient successfully reduced weight while supervised in hospital but regained it on return home. Younger patients were more co-operative. One 10year-old girl lost $5 \mathrm{~kg}$ in 5 weeks on water, apples, oranges, and vitamins in the first 3 weeks and 290 calories a day thereafter. Her parents persuaded her to continue on a diet of 300 to 800 calories a day and her weight remained static for over a year. A boy treated similarly from age 10 years remained a reasonable weight for 4 to 5 years (D MacCarthy, 1978, personal communication). Pipes and $\mathrm{Holm}^{27}$ and Holm and Pipes ${ }^{28}$ dieted 18 patients with the PW syndrome and they considered that such patients required fewer calories than normal. They recommended 8-9 calories per $\mathrm{cm}$ of height a day. Bistrian et al. ${ }^{29}$ suggested that a modified protein sparing diet reduced appetite. We agree that strict dieting is sometimes possible but it is easier to impose if the patient is young. Over age 12 years violent temper tantrums persuade the entire family to abandon the attempt. The complications of surgery for obesity in these patients are hazardous ${ }^{30-35}$ but such surgery can be successful. ${ }^{4}$ Vagotomy has been tried but longer-term studies are needed. ${ }^{36-37}$

A report ${ }^{38}$ that excess $\beta$-endorphin might play a role in the development of the overeating-obesity syndrome and that the syndrome might be overcome by the opiate antagonist, naloxone, offers a new approach. However, very preliminary experience of this drug in 3 of our patients is not encouraging. ${ }^{41}$

Most of the patients lived at home from whence they attended adult training centres. They saw their general practitioner only occasionally and were generally in psychiatric care. It is probable that some remain undiscovered in institutions for the mentally handicapped.

Excessive fat caused excessive sleep and cyanosisthe 'Pickwickian syndrome' ${ }^{39}$-and unless weight loss can be achieved such patients are likely to die from cor pulmonale.

We thank the many doctors who referred patients as well as the radiologists, psychologists, and laboratory staff who helped with investigations over many years, Professor M Besser, Dr W Jeffcoate, and Dr M Savage for constructive criticism and some of the photographs, the Photographic Department of St Bartholomew's hospital and Mr Clifford, Queen Elizabeth hospital, for the remainder of the photographs, and Miss O'Neill for typing the manuscript.

This work was partly supported by the Queen Elizabeth Hospital for Children Research Appeal Trust.

\section{References}

1 Prader A, Labhart A, Willi H. Ein Syndrom von Adipositas, Kleinwuchs, Kryptorchismus, und Oligophrenie nach myatonieartigem Zustand im Neugeborenalter (abstract). Schweiz Med Wochenschr 1956; 86: 1260-1.

2 Prader A, Labhart A, Willi H, Fanconi G. Ein Syndrom von Adipositas, Kleinwuchs, Kryptorchismus, und Idiotie bei Kindern und Erwachsenen, die als Neugeborene ein myatonie-artiges Bild geboten haben. In proceedings of the Eighth International Congress of Pediatrics, Copenhagen 1956; NE 10, 13.

3 Laurance B M. Hypotonia, obesity, hypogonadism, and mental retardation in childhood (abstract). Arch Dis Child $1961 ; 36: 690$.

${ }^{4}$ Clarren S K, Smith D W. Prader-Willi syndrome: variable severity and recurrence risk. Am J Dis Child 1977; 131 : 798-800. 
5 Wannarachue N, Ruvalcaba R H A, Kelly V C. Hypogonadism in Prader-Willi syndrome. Am J Ment Defic 1975; 79: 592-603.

6 Dunn H G. The Prader-Labhart-Willi syndrome: review of the literature and report of nine cases. Acta Paediatr Scand 1968; Supplement 186.

7 Zachman M, Prader A, Kind H P, Hafliger H, Budliger $\mathrm{H}$. Testicular volume during adolescence. Helv Paediatr Acta 1974; 29: 61-72.

8 Jeffcoate W J, Laurance B M, Edwards C R W, Besser G M. Endocrine function in the Prader-Willi syndrome. Clin Endocrinol 1980; 12: 81-9.

9 Hall B D, Smith D W. Prader-Willi syndrome. J Pediatr 1972; 81: 286-93.

10 Vischer V D, Labhart A, Prader A, Ginsberg J. Das Prader-Labhart-Willi syndrome. In: Pfeiffer E F, ed. Handbuch des Diabetes Pathophysiologie. Vol. 11. Munchen: Lehmans Verlag, 1971.

11 Jancar J. Prader-Willi syndrome (hypotonia, obesity, hypogonadism, growth, and mental retardation). $J$ Ment Defic Res 1971; 15: 20-9.

12 Gabilan J-C, Royer P. Le Syndrome de Prader, Labhardt et Willi (Etude de onze observations). Arch Fr Pediatr 1968; 25: 121-49.

13 Endo M, Tasaka Y, Matsurra N, Natsada I. LawrenceMoon-Biedl syndrome (?) and Prader-Willi syndrome (?) in a single family. Eur J Pediatr 1976; 123: 269-76.

14 Dunn H G, Ford D K, Auersperg N, Miller J R. Benign congenital hypotonia with chromosomal anomaly. Pediatrics 1961; 28: 578-91.

15 Hawkey C J, Smithies A. The Prader-Willi syndrome with a $15 / 15$ translocation. Case report and review of literature. J Med Genet 1976; 13: 152-6.

16 Fraccaro M, Zuffardi O, Bühkler E M, Jurik P L. 15/15 translocation in Prader-Willi syndrome. J Med Genet $1977 ; 14: 275-6$

17 Lucas M. Translocation between both members of chromosome pair number 15 causing recurrent abortions. Ann Hum Genet 1969; 32 : 347-51.

18 Laurance B M. Hypotonia, mental retardation, obesity, and cryptorchidism associated with dwarfism and diabetes in children. Arch Dis Child 1967; 42: 126-39.

19 Dubowitz V. Hypotonia-obesity syndrome (the PraderWilli syndrome). Clin Dev Med 1969; 31 : 65-73.

20 Illig R, Tschumi A, Vischer D. Glucose intolerance and diabetes mellitus in patients with the Prader-Labhart-Willi syndrome. Mod Probl Paediatr 1975; 12: 203-10.

21 MacMillan D R, Kim C B, Weisskopf B. Syndrome of growth resistance, obesity, and intellectual impairment with precocious puberty. Arch Dis Child 1972; 47: 119-21.

${ }^{22}$ Kauli R, Prager-Lewin R, Laron Z. Pubertal development in the Prader-Labhart-Willi syndrome. Acta Paediatr Scand 1978; 67: 763-7.

23 Seyler L E, Arulanantham K, O'Connor C F. Hypergonadotropic-hypogonadism in the Prader-Labhart-Willi syndrome. J Pediatr 1979; 94: 435-7.

24 Zellweger H, Schreider H J. Syndrome of hypotoniahypomentia-hypogonadism-obesity (HHHO) or PraderWilli-syndrome. Am J Dis Child 1968; 115: 588-99.
25 Hamilton C R, Jr, Scully R E, Kliman B. Hypogonadotropism in the Prader-Willi syndrome: induction of puberty and spermatogenesis by clomiphene citrate. Am J Med 1972; 52: 322-9.

${ }^{26}$ Katcher M L, Bargman G J, Gilbert E F, Opitz J M. Absence of spermatogonia in the Prader-Willi syndrome. Eur J Pediatr 1977; 124: 257-60.

27 Pipes P L, Holm V A. Weight control of children with Prader-Willi syndrome. J Am Diet Assoc 1973; 62: 520-4.

28 Holm V A, Pipes P L. Food and children with PraderWilli syndrome. Am J Dis Child 1976; 130: 1063-7.

29 Bistrian B R, Blackburn G L, Stanbury J B. Metabolic aspects of a protein-sparing modified fast in the dietary management of Prader-Willi obesity. N Engl J Med 1977; 296: 774-9.

30 Randolph J G, Weintraub W H, Rigg A. Jejuno-ileal bypass for morbid obesity in adolescents. $J$ Pediatr Surg 1974; 9: 341-5.

31 Bode H H, Bolstein P M, Crawford J D, et al. Vergleich medizinischer und chirurgescher Behandlung der hypothalamischen Fettsucht im Kindesalter. Infusiontherapie 1975; 2: Supplement 3, 7-10.

32 Soper R T, Mason E E, Printen K J, Zellweger H. Gastric bypass for morbid obesity in children and adolescents. $J$ Pediatr Surg 1975; 10: 51-8.

${ }^{33}$ Griffen W O, Jr, Young V L, Stevenson C C. A prospective comparison of gastric and jejuno-ileal bypass procedures for morbid obesity. Ann Surg 1977; 186: 500-9.

34 Mason E E, Ito C. Gastric bypass. Ann Surg 1969; 170: 329-39.

35 Blackburn G L, Bistrian B R. Surgical techniques in the treatment of adolescent obesity. In: Collipp $\mathbf{P} \mathbf{J}$, ed. Childhood obesity. Acton, Mass: Publishing Sciences Group, 1975: 117.

${ }^{36} \mathrm{Kral}$ J G. Vagotomy for treatment of severe obesity. Lancet 1978 ; i: 307-8.

37 Mordes J P, Silen W. Letter: Vagotomy for severe obesity. Lancet 1978: i: 775.

38 Margules D L, Moisset B, Lewis M J, Shibuya H, Pert C B. $\beta$-Endorphin is associated with overeating in genetically obese mice $(\mathrm{ob} / \mathrm{ob})$ and rats $(\mathrm{fa} / \mathrm{fa})$. Science $1978 ; 202$ : 988-91.

39 Burwell C S, Robin E D, Whaleg R D, Bickelman A G. Extreme obesity associated with alveolar hypoventilation -a Pickwickian syndrome. Am J Med 1956; 21 : 811-8.

40 Pearson K D, Steinbach H L, Bier D M. Roentgenographic manifestations of the Prader-Willi syndrome. Radiology 1971; 100: 369-77.

41 Kyriakides M, Silverstone T, Jeffcoate W, Laurance B. Letter: Effect of naloxone on hyperphagia in Prader-Willi syndrome. Lancet 1980; i: 876-7.

Correspondence to $\mathrm{Dr}$ B M Laurance, Queen Elizabeth Hospital for Children, Hackney Road, London E2 8PS.

Received 6 December 1979 